\title{
The effects of winter severity and population density on body stores in the Iberian wild goat (Capra pyrenaica) in a highly seasonal mountain environment
}

\author{
Emmanuel Serrano \& Jose Enrique Granados \& \\ Mathieu Sarasa \& Francisco Jose González \& \\ Paulino Fandos \& Ramon C. Soriguer \& Jesus M. Pérez
}

\begin{abstract}
We studied the factors that determined kidney fat stores (KFs) and kidney stores (Ks) — defined as the residuals from the linear regression of kidney mass and kidney fat, respectively, on body weight-in 463 Iberian wild goats (Capra pyrenaica) from the Sierra Nevada (southern Spain). Despite the fact that body stores in both sexes were highest during the warmest months of the year and lowest during the coldest months when food resources are limited, the observed pattern was sex- and agedependent. The KFs of male goats fell more than those of females in winter, and the yearlings of both sexes needed one season more than young or adults to restore their KFs.
\end{abstract}

Communicated by H. Kierdorf

Electronic supplementary material The online version of this article (doi:10.1007/s10344-010-0398-5) contains supplementary material, which is available to authorized users.

E. Serrano ( $\star *)$

Servei d'Ecopatologia de Fauna Salvatge, Facultat de Veterinària, Universitat Autònoma de Barcelona,

E-08193 Bellaterra,

Barcelona, Spain

e-mail: emmanuel.serrano@uab.cat

J. E. Granados

Espacio Natural de Sierra Nevada,

Carretera Antigua de Sierra Nevada,

km 7, E-18071 Pinos Genil,

Granada, Spain

M. Sarasa

Laboratoire Comportement et Ecologie de la Faune Sauvage, Institut National de la Recherche Agronomique,

F-31326 Castanet-Tolosan, France

F. J. González

Laboratorio Prolab,

C/ Carrera, 62, E-23600, Martos, Jaén, Spain
Goats of all age classes showed the same seasonal patterns in their Ks, although Ks were lower in females than in males throughout the yearly cycle. In addition, we found strong delayed effects of both snowfalls and population density on body stores, and in years with a lot of snow, goats' KFs reached their lowest levels in the current winterspring, but the highest in the following summers and autumns. This pattern was less noticeable in the Ks. Population density negatively affected the body stores of wild goats, especially in winter, and the amount of snow fallen in the year of birth (cohort effect) did not seem to influence the body stores in our data set. In addition, we

P. Fandos

EGMASA,

Av. Johan G. Gutenberg, s.n,

Isla de la Cartuja E-41092 Sevilla, Spain

R. C. Soriguer

Estación Biológica de Doñana (C.S.I.C),

Av. Americo Vespucio, s.n,

E-41092, Spain

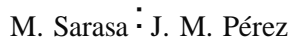

Departamento de Biología Animal, Biología Vegetal y Ecología,

Facultad de Ciencias Experimentales, Universidad de Jaén,

Campus Las Lagunillas, s.n,

E-23071 Jaén, Spain 
assessed the accuracy of the residuals from the regression between body size and body mass for monitoring body condition of live wild goats and concluded that, although it poorly indicates fat stores, it could be used as a general proxy of body condition. Finally, we discuss the expected effects of climate warming on body stores in this Mediterranean Caprinae species.

Keywords Body condition - Capra pyrenaica - Climatic conditions · Density-dependence $\cdot$ Mass-size residuals . Sexual dimorphism

\section{Introduction}

Many mammalian species display a wide range of physiological and behavioural adaptations that compensate for variations in resource availability and energetic requirements (Levins 1968). In ungulates, one of the most common such adaptation is the increase in the size of adipose tissues and organs-or 'body stores' (King and Murphy 1985)—in anticipation of periods of shortage by means of hyperphagia during periods of food abundance (Barboza and Hume 2006). This common adaptive syndrome, which provides clear advantages when coping with changing environmental conditions, is typical of migrating vertebrates and species inhabiting seasonal environments (Piersma and Drent 2003).

Changes in body condition-this term includes tissues necessary for a functionally normal life (defined as 'body reserves', according to Lindström and Piersma 1993) and those accumulated in anticipation of periods of shortage (defined as 'body stores', according to King and Murphy 1985) — have been related to several life-history traits in several ungulate species (Serrano et al. 2008a). Commonly, this group of mammals allocates large amounts of energy to each breeding attempt (Pélabon et al. 1995) and exhibits a wide range of resource-use tactics within the income-capital breeder continuum (Jönsson 1997).

Changes in body condition have been related to several life-history traits in ungulate species. Aside from the energetic needs of reproduction, these mammals also have sex- and age-specific energetic requirements (Stamps 1993). Male ungulates are typically heavier, require more energy for growth and mature at larger sizes than females and hence are more prone to suffer during food shortages (Clutton-Brock et al. 1981, Andersson 1994). Young ungulates are especially vulnerable when food is scarce due to their high energetic growth requirements (Lesage et al. 2001).

Besides these sex- and age-specific energetic requirements, ungulate body condition is also environment- and density-dependent. For example, in mountainous and northern regions, the best body conditions coincide with the main period of plant growth (Flydal and Reimers 2002) and the worst with winter. In this latter period, low temperatures and deep snow increase the cost of thermoregulation (Jensen et al. 1999), locomotion (Dailey and Hobbs 1989) and diminish browsing opportunities (Goodson et al. 1991, Visscher et al. 2006), thereby depleting the body condition achieved during the warmer seasons.

Additionally, it is well-known that increases in population density lead to foraging competition (Choquenot 1991; Post and Stenseth 1999) and thus affect the budget and allocation of energetic tissues (Stewart et al. 2005). These factors may even influence the body stores of animals throughout the whole of their lives, a process that Forsyth et al. (2005) have termed the 'cohort effect'. Gender-, age- and environment-determined influences on body stores (only considering fat tissues) have been reasonably well-studied in cervids (see Mitchell et al. 1976; Bishop et al. 2005) and rarely in bovids (Forsyth et al. 2005). However, to our knowledge, the influence of these factors on organ stores (organ tissues) in freeranging ungulates has been studied just once in cervids (Yokoyama et al. 2001) but never in bovids. To assess the role of environmental and population drivers on the use of both kind of body stores will be necessary for understand the eco-physiologycal adaptations of this mammals and for assessing new indicators of body condition in wildlife monitoring programmes.

The Iberian wild goat (Capra pyrenaica) is a dimorphic ungulate that is endemic to the mountains of the Iberian Peninsula (Pérez et al. 2002). One of the best populations for exploring the effects of climatic conditions on body stores is found in the Sierra Nevada mountains (southern Spain), where wild goats experience a highly contrasting seasonal cycle each year (Consejería de Medio Ambiente 2004) consisting of 6 months of snow $\left(0.5^{\circ} \mathrm{C}\right.$ and $98.79 \mathrm{~mm}$ monthly mean temperature and precipitation) and followed by six of drought $\left(23^{\circ} \mathrm{C}\right.$ and $35 \mathrm{~mm}$ monthly mean temperature and precipitation).

In this work, we examine the influence of sex and age on the seasonal pattern of body stores in culled wild goats from the Sierra Nevada. We also evaluate how winter severity (the amount of snow fallen during the first winter of life and during the last winter before being culled) and population density in the last year of life influence body stores in this mountain ungulate. Specifically, we tested the following predictions: (1) as has been reported in other ungulate species, inhabiting environments with markedly seasonal conditions (Mysterud et al. 2004; Festa-Bianchet et al. 2000), the body stores of Iberian wild goats should recover from winter lows as summer progresses into autumn and the rutting season begins; (2) in a high mountain environment such as the Sierra Nevada, with 
strong seasonal climatic variations and reduced plant productivity, male goats should accumulate lower body stores than females due to their higher energetic requirements; (3) body stores in yearlings and young should be more sensitive to changing conditions than those of adults due to the trade-off between growth and body condition and their poorer ability to adapt to fasting (an example in a Cervidae species in Vincent et al. 1995); (4) given their relationship with foraging competition, body stores should be density-dependent; (5) snowfalls reduce food availability, and so, winter conditions during the first year of life and the last winter before being shot should also affect goats' body stores (Loison and Langvatn 1998).

Finally, taking into account the fact that most methods for measuring fat stores require necropsy (Serrano et al. 2008a), we evaluated whether or not the residuals from the linear regression between body size and body mass (named 'mass-size residuals', according to Green 2001) are useful for predicting fat reserves in wild goats.

Material and methods

Study area

The Sierra Nevada is a Mediterranean mountain range extending over 1,690 $\mathrm{km}^{2}$ (36 $\left.55^{\circ}-37^{\circ} 10^{\prime} \mathrm{N} 2^{\circ} 56^{\prime}-3^{\circ} 38^{\prime} \mathrm{W}\right)$, with altitudes ranging from 1,400 to $3,481 \mathrm{~m}$ asl. This area is very altitudinally stratified: above-2,800-m pastures are exposed to strong winds in summer and to snow during much of the year; from 1,900 to $2,800 \mathrm{~m}$, broom-juniper formations and cushions of thorny chamaephytes dominate along with abundant Scots pine Pinus silvestris forests and hygrophilous meadows containing waterlogged hollows in summer; finally, evergreen oak Quercus rotundifolia forests with the broom Adenocarpus decorticantis are found between 1,400 and 1,900 $\mathrm{m}$ (Varios 1987).

This mountainous ecosystem is characterised by strong seasonal climatic variations; snow covers the landscape for 6 months (December to May), and most plant growth occurs in a period of just 3 months (JuneAugust). The phenology adopted in this study was as follows: winter, December 15-March 5; spring, March 6-June 15; summer, June 16-September 15; and autumn, September 16-December 14.

Iberian wild goat population and sampling procedures

During a 9-year sampling period (1996-2004), 463 Iberian wild goats (318 males and 145 females) were shot-harvested without any particular criteria within each sex and age class by the Sierra Nevada National Park staff as part of a management programme. After culling, animals' sex was assigned by visual inspection; age was assessed by counting horn segments (Fandos 1991), and basic biometry (Granados et al. 1997) was measured to the nearest $0.5 \mathrm{~cm}$ with a nylon tape measure. Subsequently, goats were weighed to the nearest $0.1 \mathrm{~kg}$ with a spring scale and were then eviscerated. The two kidneys with their fat were removed and blotted dry with a paper towel. The fat surrounding both ends of the kidney was removed by peeling away the peritoneal membrane (see Riney 1955), and the fat-free kidney mass (KM) and associated fat (KF) were then weighed to the nearest $0.01 \mathrm{~g}$. The average weight of the two KMs and KFs was calculated (Table S1, supplementary material). During the whole study period, the sampling procedures and protocols were supervised by J. E. G. in order to minimise inter-observer variability.

Density and climatic data

Since 1992, a management programme aimed at reducing goat densities and controlling sarcoptic mange (Sarcoptes scabiei), a parasitic disease affecting this population (Pérez et al. 1997), has been in progress. With the exception of 1999 and 2000, between 1996 and 2003, every summer, goat densities were estimated by distance sampling (e.g., Buckland et al. 2001 for a general reading and Pérez et al. 1994; Pérez and Alpizar-Jara 2008 as examples) following the same sampling design (effort and itineraries). To satisfy the assumption that every observation was an independent event, observations were made of clusters of animals (Chen 1996). Density estimates were obtained using distance 5.0 beta (Thomas et al. 2005). Snowfall data (millimetres of water) were recorded from November to April at the Pradollano meteorological station located in the study area at 2,555 $\mathrm{m}$ asl, $\left(37^{\circ} 09^{\prime} \mathrm{N} \mathrm{3} 3^{\circ} 23^{\prime} \mathrm{W}\right)$.

\section{Statistical analysis}

We grouped animals into three age classes according to their body growth and skeletal maturation (Serrano et al. 2006, Granados et al. 2001): yearlings ( $1 \leq$ age $\leq 2$ years); prime age females and growing males (2 years $\leq$ age $\leq$ 5 years, called young animals hereafter) and adults ( $\geq 5$ years).

Both KM and KF are positively correlated to nutritional status in Iberian wild goats (Serrano et al. 2008b) and to body condition in a great range of mammals of different body sizes (from roe deer to moose, Serrano et al. 2008a). As predicted, heavier goats (skeletally bigger and fatter) had more $\mathrm{KM}\left(\mathrm{R}^{2}=0.73, \mathrm{~F}_{1,461}=1,281 ; \mathrm{p}<0.01\right.$, linear relationship between body weight and $\mathrm{KM}$ ) and $\mathrm{KF}$ $\left(R^{2}=0.26, F_{1,461}=159.5 ; p<0.01\right.$ following the same procedure) than lighter ones. Consequently, we defined the kidney stores (Ks) and kidney fat stores (KFs) as the residuals from the linear regression of $\mathrm{KM}$ or $\mathrm{KF}$, 
respectively, on body weight. The weights of kidneys and their attached fat were subtracted from body weight to avoid spurious correlations (Christians 1999). We assumed that both Ks and KFs are proxies of body stores.

Before calculating either the Ks or KFs, we tested to see whether the relationships between body weight and FM and $\mathrm{KF}$ were linear (by comparing with alternative models, results not shown) and whether their slopes were constant between the different treatments (sex, age classes and seasons). When the slopes varied between treatments (e.g. between age classes for the regressions between body weight-KM or between body weight-KF, results not shown), we extracted the residuals from each homogeneous group (García-Berthou 2001).

Once both the Ks and KFs had been estimated, we fitted a set of generalised additive mixed models in a first explanatory analysis as a means of analysing whether or not sex, age, the month of culling (as a smoothed factor) and their two- and three-way interactions affected the KFs and Ks values in these Iberian wild goats. We used additive models because they are especially useful when non-linear relationships between responsive and explanatory variables (e.g. KFs or Ks and month of the year) occur (Wood 2006). In this first model selection, we did not consider any additional environmental factors to explain inter-annual variation (e.g. population density) in the KFs and Ks; thus, the year of collection was taken as a random factor to prevent temporal pseudo-replication (Zuur et al. 2009).

To explore the environment- and density-dependence of body stores, we used the samples obtained during the periods in which population densities were recorded (19961998 and 2001-2003). We analysed whether KFs and Ks (mean values for each sex, age class and cohort) were influenced by population density (as experienced in the previous year) and winter severity (during the first winter or last winter of life) and their two- and three-way interactions by fitting a set of linear models. Due to the lack of samples for some months and on the basis of the results obtained in the first analysis, data were pooled for two periods of contrasting body stores: winter-spring, when goats had the lowest body stores $(n=151)$ and summer-autumn, when body stores were highest $(n=149)$. Winter severity was defined as the log-transformed snowfall (to control for heterocedasticity) during the first or last winter of life (firstsnow and last-snow, hereafter). To prevent multicollinearity, the lack of linear correlation between first-snow and lastsnow was verified in winter-spring and in summer-autumn.

Finally, to assess whether the mass-size residuals were appropriate for estimating fat reserves in live wild goats, we performed a linear regression (the linear fit was the best after comparing several linear and non-linear models, results not shown) between the log-transformed body mass (with viscera) on shoulder height (distance from the goat's hooves to the top of the scapula), one of the best predictors of body weight in this species (Fandos et al. 1987). Before obtaining the residuals, we checked the linearity and homogeneity of slopes in sex and age classes and in the two periods of fat storage considered in the second analysis. Once the residuals were obtained for each sex and age class category (their slopes differed significantly, results not shown), we fitted a set of linear models to study the relationship between the mass-size residuals and the logtransformed KF for sex, age classes and periods of fat storage and their two- and three-way interactions.

We used the Kullback-Leibler information-theoretic approach as the distance between the various candidate models and full reality (Anderson et al. 2001; Johnson and Omland 2004). We computed the Akaike Information Criterion corrected for small samples (AICc) for each of the candidate models and selected the model with the lowest AICc value (Burnham and Anderson 2002). We then ranked the remaining competing models according to their AICc value and subsequently estimated their Akaike differences $(\Delta \mathrm{i})$ with respect to the best model (lowest AICc), the Akaike weight $\left(\mathrm{W}_{\mathrm{i}}\right)$ of each model and the relative importance (RI) of the exploratory variables (Burnham and Anderson 2002). All statistical analyses were performed using $\mathrm{R}$ software version 2. 9. 2 (R Development Core Team 2009).

\section{Results}

The raw values of kidney fat and fat-free kidney mass according to sex, age class and season are given in the supplementary material (Table S1).

\section{Kidney fat stores}

In the Sierra Nevada, the KFs of the Iberian wild goats showed a sex- and age-dependent seasonal pattern $\left(\mathrm{W}_{\mathrm{i}}\right.$ seasons* sex + age $=0.68,32.3 \%$ deviance explained, Table 1). Animals had a negative energetic balance for more than 6 months of the year, with the lowest KFs being found in early spring and the highest in autumn, when the full KFs is restored (Fig. 1a).

Besides this clear seasonal pattern, there were also particular trends in each sex. For example, from January to April (snowy season), females had 2.6 times (estimated as average KFs in females/average KFs in males) more KFs than males, although, from May to August, males were able to store 1.7 times more KFs than females. During August, this trend was inverted, and male KFs decreased as female KFs increased, reaching a peak in October. This pattern is the same in wild goats of all age classes. However, the younger classes (especially yearlings) restored their KFs a 
Table 1 Model selection of variation in kidney fat stores (KFs) in Iberian wild goats

\begin{tabular}{|c|c|c|c|c|}
\hline KFs & $\mathrm{K}$ & $\mathrm{AICC}$ & $\Delta \mathrm{i}$ & $\mathrm{W}_{\mathrm{i}}$ \\
\hline \multicolumn{5}{|l|}{ General model $(n=463)$} \\
\hline Seasons *sex + age & 15 & $1,217.24$ & 0 & 0.68 \\
\hline Seasons*age + aex & 20 & $1,220.92$ & 3.68 & 0.11 \\
\hline Seasons + sex $*$ age & 15 & $1,221.04$ & 3.80 & 0.10 \\
\hline Sesons*sex & 14 & $1,221.06$ & 3.81 & 0.10 \\
\hline Seasons*age & 19 & $1,225.31$ & 8.06 & 0.01 \\
\hline \multicolumn{5}{|c|}{ Models for evaluating the snow and density-dependence effects $(n=300)$} \\
\hline Period $*$ density + period $*$ last-snow + sex + age & 10 & 775.58 & 0 & 0.88 \\
\hline Period*density + sex + age & 8 & 780.59 & 5.01 & 0.07 \\
\hline Period*sex*density+age & 11 & 783.23 & 7.64 & 0.02 \\
\hline Period*sex + last-snow + density + age & 9 & 784.28 & 8.70 & 0.01 \\
\hline Period + sex + age* density & 9 & 784.44 & 8.86 & $>0.01$ \\
\hline
\end{tabular}

$\mathrm{K}$ number of parameters, including both the intercept and the error terms, AICc Akaike's Information Criterion corrected for small sample size, $\Delta \mathrm{i}$ difference of AICc with respect to the best model, $W_{i}$ Akaike weight, last-snow log-transformed snowfall in the winter previous to the animal's death, first-snow log-transformed snow fallen during the first winter of life, density wild goats per square kilometre in summer, period contrasted periods of fat storage, from November to April (when goats depleted their fat stores) and from May to October (when goats recovered their fat stores). In bold, the selected model. Only models with any support for being the best model $(\Delta \mathrm{i}<10$ units $)$ are shown. The asterisk "*” means interaction between terms
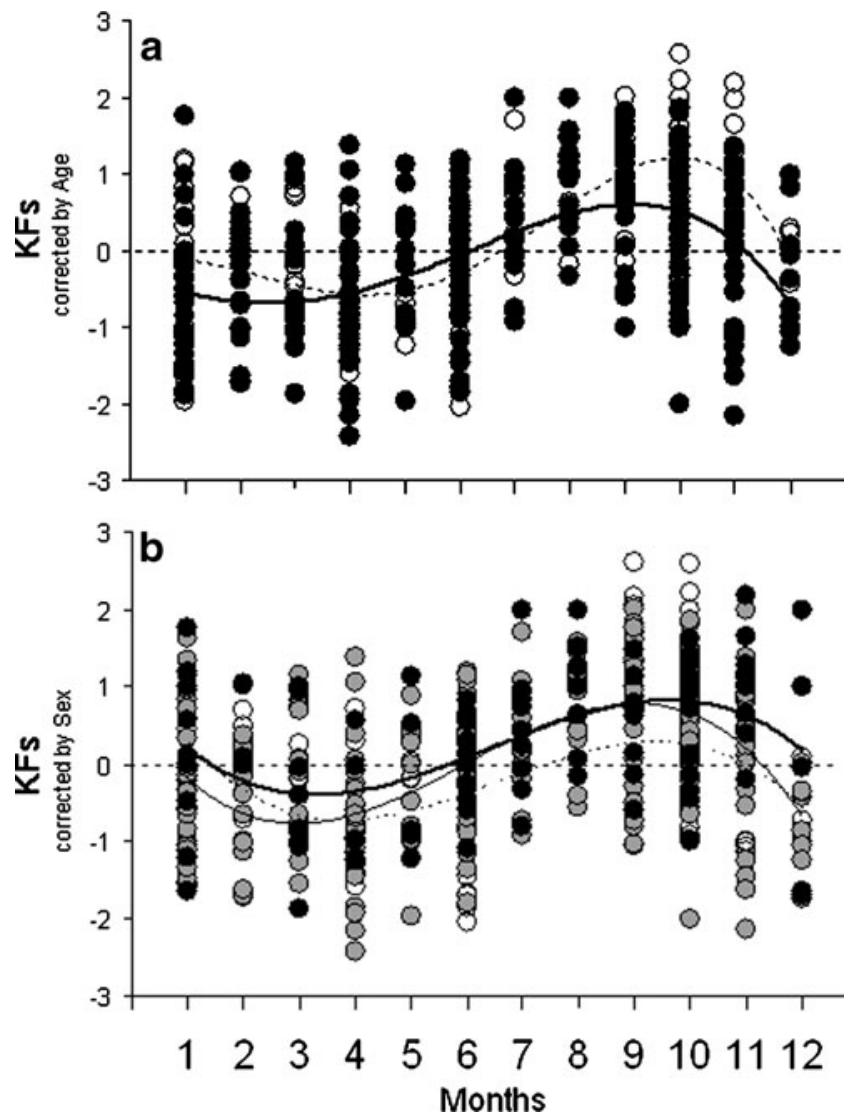

Fig. 1 Seasonal variations in kidney fat stores (KFs) in: a female (dashed line and white circles) and male (solid line and black dots) and $\mathrm{b}$ in yearlings ( 1 year $\leq$ age $<2$ year, dashed line and circles), young animals ( 2 years $\leq$ age $<5$ years, thin line and grey circles) and adults ( $\geq 5$ years, solid line and black dots) Iberian wild goats in the Sierra Nevada (southern Spain) month later than adults and depleted their KFs 1 month earlier (Fig. 1b).

The negative influence of winter severity (in the last winter before the animal was culled) and population density on KFs was clear $\left(\mathrm{RI}_{\text {last-snow }}=0.89\right.$ and $\left.\mathrm{RI}_{\text {density }}=0.99\right)$ in the wild goats in the Sierra Nevada $\left(\mathrm{W}_{\mathrm{i} \text { period*density + period* }}\right.$ last-snow + sex + age $=0.88,32 \%$ variance explained, Table 1). During the cold period (winter-spring), both winter severity (slope $=-0.17, \mathrm{SE}=0.15$, from the regression last-snow vs. KFs, Fig. 2) and population density in the preceding year (slope $=-0.422, \mathrm{SE}=0.061$, from the regression population density vs. KFs, Fig. 3) negatively affected the amount of

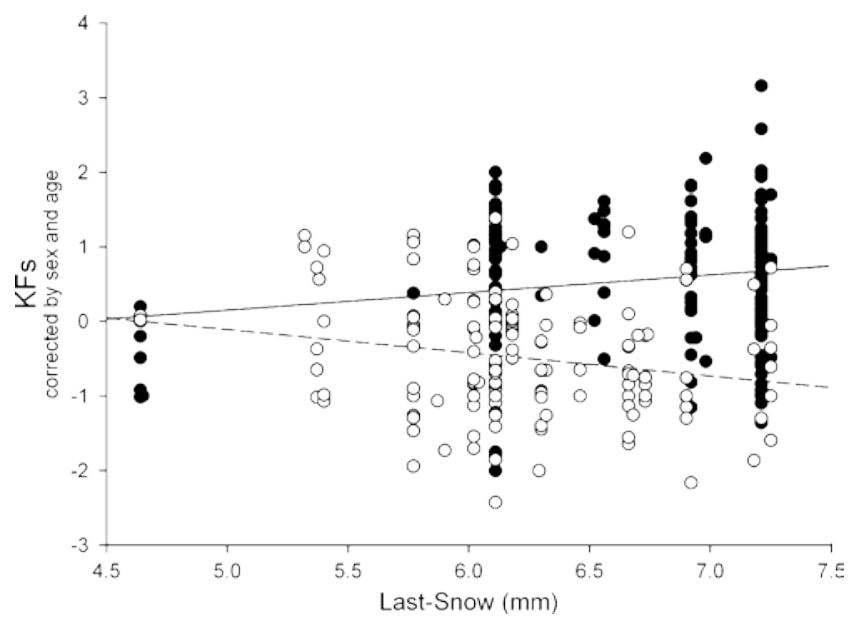

Fig. 2 Effect of winter severity (Last-Snow: millimetres of snowfall in the previous winter) on kidney fat stores (KFs) in winter-spring (dashed line and circles) and in summer-autumn (solid line and black dots) 


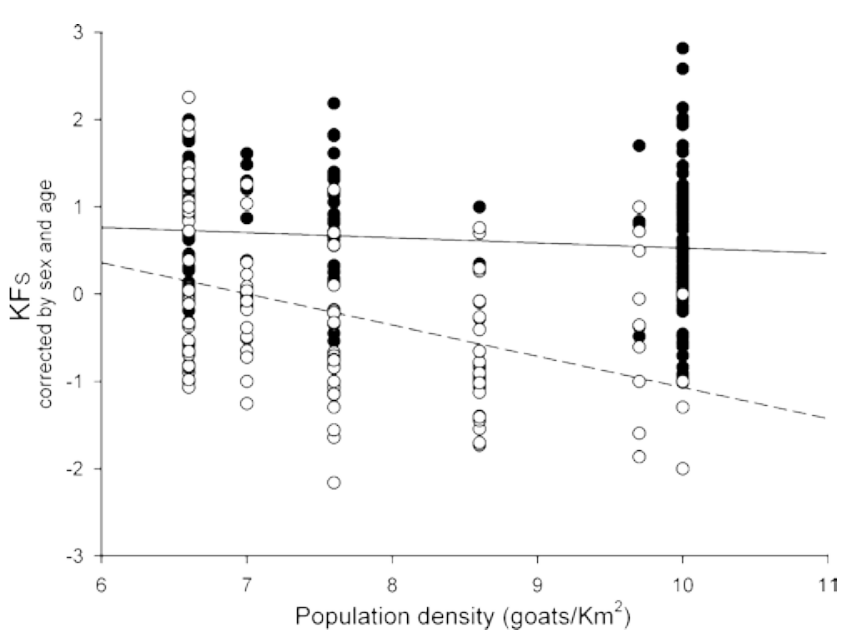

Fig. 3 Effect of population density (goats per square kilometre) in the preceding summer on kidney fat stores (KFs) in winter-spring (dashed line and circles) and in summer-autumn (solid line and black dots)

KFs stored in the current year. In fact, in very snowy years or in years with high population densities, mean KFs were, in some cases, over three times lower.

However, both effects depend on the period of the year and in the Sierra Nevada the density-dependence of KFs diminished in summer (slope $=-0.031, \mathrm{SE}=0.039$, Fig. 3), whereas goats of all sex and age classes had greater KFs if the previous winter had had abundant snowfall (slope= 0.027, SE =0.082, Fig.2). The amount of snow during the first year of life (first-snow) did not seem to influence $\left(\mathrm{RI}_{\text {last-snow }}<0.1\right)$ the KFs in either spring or summer and autumn (Table 1).

\section{Kidney stores}

As for fat stores, the Ks were season-dependent. Despite again finding sexual differences $\left(\mathrm{W}_{\mathrm{i} \text { seasons } * \text { sex }}=0.83,12.5 \%\right.$ deviance explained, Table 2), goats had the lowest Ks in winter (December and January) and the highest in spring and summer (May to July, Fig. 4). When the depletion of the Ks occurs in the period September-January, males reduced their summer reserves 1.34 times, while females did so 1.14 times. However, at the end of winter, male goats increased their Ks faster than females and, by June, had 1.1 times more Ks than females. According to our model selection procedure, goats' ages do not influence the trend in Ks.

Surprisingly, winter severity did not seem to influence either winter or summer Ks and, indeed, female and male wild goats of all age classes enhanced their Ks in winters with heavy snowfalls $\left(\mathrm{W}_{\mathrm{i}}\right.$ period density+last-snow + sex $=0.68$, $23.8 \%$ variance explained, Table 2, Fig. 5). In years with abundant snow, the mean Ks of both sexes could be as much as 3.8 times greater (maximum Ks in the snowiest year/minimum Ks in the least snowy year) than in years with little snow. In Ks, seasonal density-dependence occurred and winter-spring Ks were negatively affected in years with high population densities (slope $=-8.01, \mathrm{SE}=$ 1.69, Fig. 6). Despite the fact that population densities and winter severity are clearly influential $\left(\mathrm{RI}_{\text {last-snow }}=0.88\right.$ and $\mathrm{RI}_{\text {density }}=0.78$ ), the winter conditions experienced during the first year of life did not appear to influence Ks at culling $\left(\mathrm{RI}_{\text {last-snow }}<0.1\right)$.

\section{Mass-size residuals as predictors of kidney fat}

We found a positive relationship between mass-size residuals and kidney fat $\left(R^{2}=0.2\right.$, slope $=0.1, S E=0.005$ and $\triangle \mathrm{AICc}=28.46$ respect to the null model including only the intercept and error term; note that, according to Burnham and Anderson (2002), models with $\Delta$ AICc $>10$ do not have any support for explain the observed variability) that varied according to sex and the fat-storage period $\left(\mathrm{W}_{\mathrm{i} \mathrm{KF}} *\right.$ sex + KF* period $=0.46$, Table 3, Fig. 7). Specifically, the mass-size residuals predicted the KF much better in females $\left(R^{2}=18.1\right.$, slope $\left.=0.04, S E=0.01\right)$ than in males $\left(R^{2}=1.17\right.$, slope $\left.=0.01, S E=0.007\right)$, above all in the warm period. When the KF depletion occurs in winter-spring, on the other hand, the mass-size residuals were poor predictors
Table 2 Model selection of the analysis of variation of kidney stores (Ks) in Iberian wild goats. In bold, the selected model

\begin{tabular}{lcccc}
\hline Ks & $\mathrm{K}$ & AICc & $\Delta \mathrm{i}$ & $\mathrm{W}_{\mathrm{i}}$ \\
\hline General model $(\mathrm{n}=463)$ & & & & \\
Seasons $\times$ sex & 14 & $3,731.43$ & 0 & 0.83 \\
Seasons $\times$ sex + age & 15 & $3,735.34$ & 3.92 & 0.12 \\
Seasons & 9 & $3,738.14$ & 6.71 & 0.02 \\
Seasons + sex & 11 & $3,739.87$ & 8.44 & 0.01 \\
Models for evaluating the snow and density-dependence effects $(\mathrm{n}=300)$ & & \\
Period $\times$ density +last-snow +sex & 7 & $2,737.91$ & 0 & 0.68 \\
Period $\times$ sex $\times$ last-snow & 9 & $2,740.79$ & 3.12 & 0.14 \\
Period $\times$ sex $\times$ density & 9 & $2,741.55$ & 3.88 & 0.09 \\
Period $\times$ last-snow + sex & 6 & $2,743.221$ & 5.21 & 0.05 \\
Period $\times$ density + sex & 6 & $2,745.69$ & 7.68 & 0.01 \\
\hline
\end{tabular}




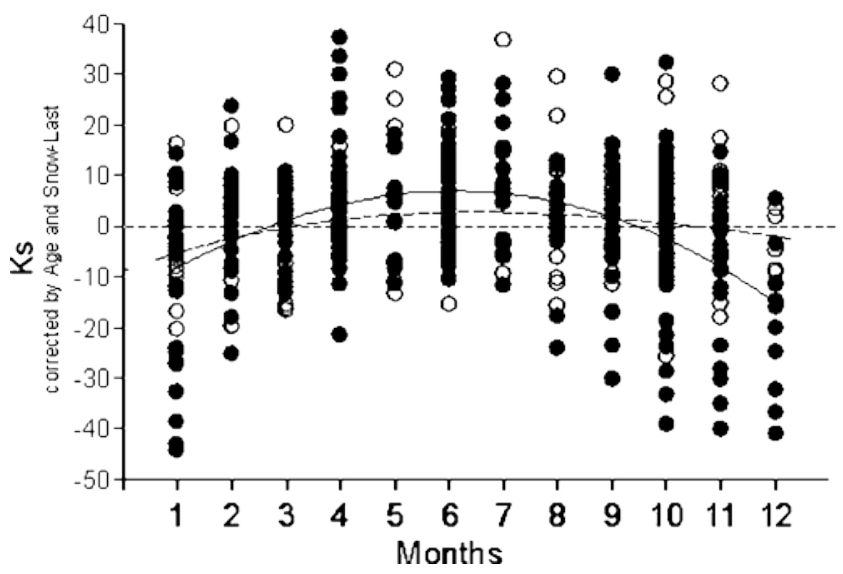

Fig. 4 Seasonal variations in kidney stores (Ks) in female (dashed line and circles) and male (solid line and black dots) Iberian wild goats in the Sierra Nevada (southern Spain)

of KF in both females $\left(R^{2}=2.017\right.$, slope $\left.=0.01, S E=0.016\right)$ and males $\left(R^{2}=0.07\right.$, slope $=0.004$, $\left.S E=0.006\right)$.

\section{Discussion}

The Iberian wild goats from the Sierra Nevada showed seasonal flexibility in their body stores. In line with our first prediction, the highest body stores occurred during the productive warm seasons and the lowest during the cold period characterised by limited food resources. Nevertheless, KFs and Ks did exhibit certain particular patterns: once winter was over, Ks recovered quicker than KFs and during autumn KFs (but not Ks) continued to increase (Figs.1 and 4). These observed variations in the KFs agree with the patterns described in several cervids (Sæther and Gravem 1988; Ferguson and Messier 2000) and bovids (Pérez-Barbería et al. 1998) and underlines the ability of this mountain ungulate to store energetic tissues as a means

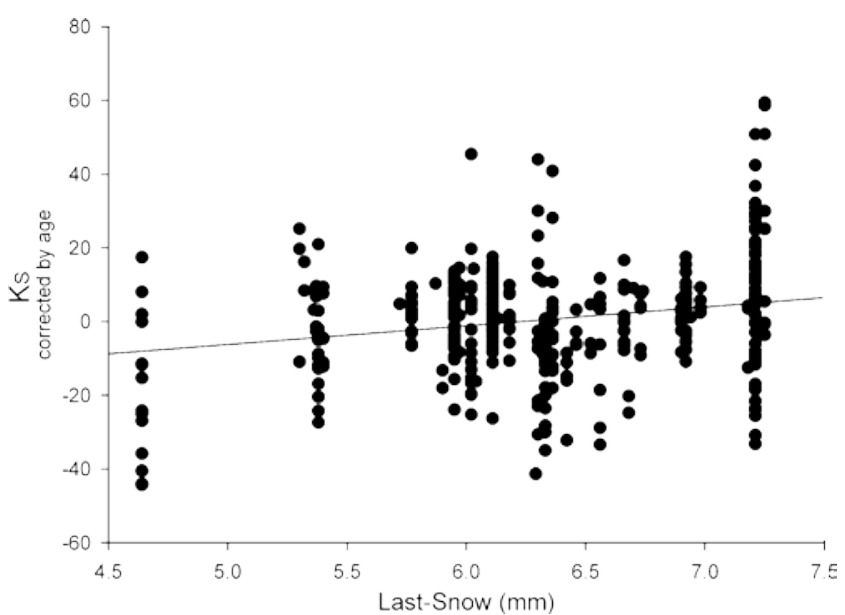

Fig. 5 Effect of winter severity (Last-Snow: millimetres of snowfall in the previous winter) on kidney stores (Ks) in the Iberian wild goat

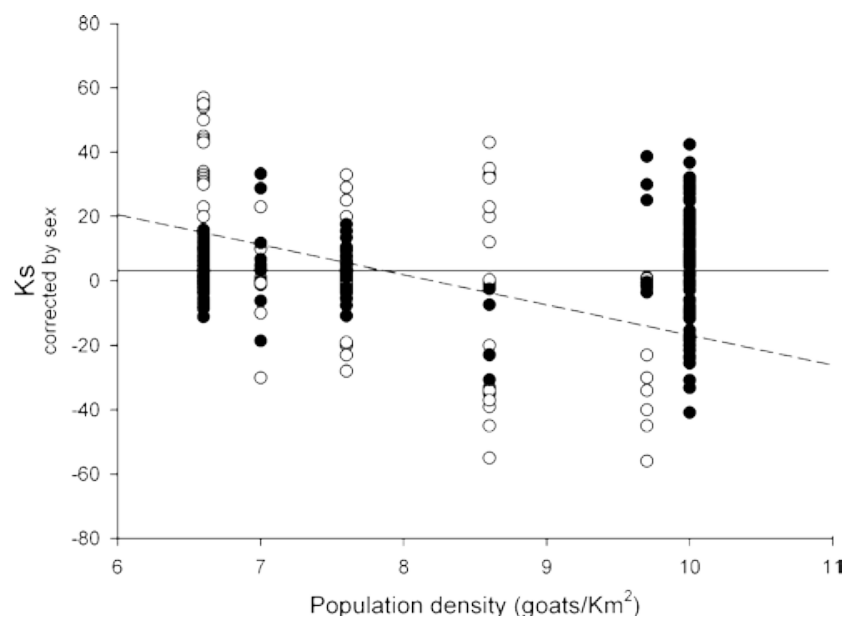

Fig. 6 Effect of population density (goats per square Kilometre) in the preceding summer on kidney stores (Ks) in winter-spring (dashed line and circles) and in summer-autumn (thick line and black dots)

of coping with fluctuating resource availability. Although seasonal variations in the size of organs have been described in several bird species, they have been reported far less frequently in free-ranging ungulates. In experiments on fasting and re-feeding in deer (Brown et al. 1995; Verme and Ozoga 1980) and sheep (Burrin et al. 1992; Burrin et al. 1990), it has been observed that organ weights may be reduced by cellular atrophy during a fasting period, but that they recover in size and function once food is available. This ability has also been described in North African breeds of sheep that experience long periods of food scarcity (Kabbali et al. 1992a) and is probably a widespread ability in ungulates inhabiting seasonal environments. Despite their main function as a filter of metabolic wastes (Torbit et al. 1985b), kidneys also play an important role in protein synthesis-about $40 \%$ of this process occurs in the gastrointestinal tract, liver and kidneys (Ferrel and Jenkins 1985) - and in the water budget (Scmidt-Nielsen and O'Dell 1961). In the Sierra Nevada, the most protein-rich and digestible food items for wild goats are found during spring and early summer (Martínez 2000). In addition, the kidney mass of this Caprinae species is directly related with

Table 3 Model selection of the analysis of variation of mass-size residuals in Iberian wild goats

\begin{tabular}{lllll}
\hline Mass-size residuals $(\mathrm{n}=463)$ & $\mathrm{K}$ & AlCc & $\Delta \mathrm{i}$ & $\mathrm{W}_{\mathrm{i}}$ \\
\hline $\mathrm{KF} \times$ sex + KF $\times$ period & 7 & -279.25 & 0 & 0.46 \\
$\mathrm{KF} \times$ sex & 5 & -278.15 & 1.06 & 0.276 \\
$\mathrm{KF} \times$ age & 7 & -276.70 & 2.50 & 0.134 \\
$\mathrm{KF} \times$ sex $+\mathrm{KF} \times$ age & 7 & -276.53 & 2.67 & 0.123 \\
\hline
\end{tabular}

Period contrasted periods of fat storage, from November to April (when goats depleted their fat stores) and from May to October (when goats recovered their fat stores). In bold, the selected model 

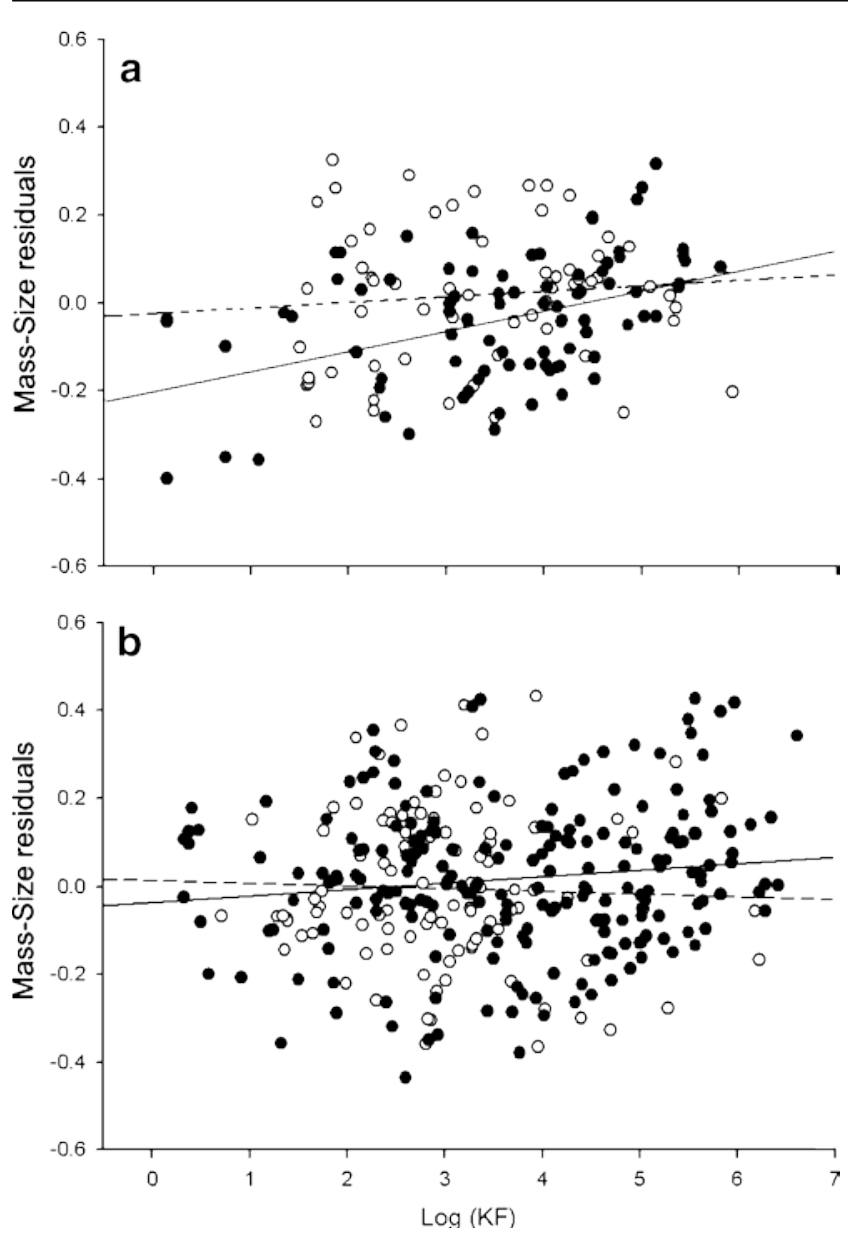

Fig. 7 Relationship between log-transformed kidney fat (Log KF) and the residuals from the linear regression between shoulder height and body mass in a female and b male Iberian wild goats in winterspring (solid line and black dots) and summer-autumn (dashed line and circles)

the serum total proteins (Serrano et al. 2008b), suggesting that the increased availability of food in the warm season (the main plant growth period) will stimulate the rapid recovery of the kidneys and their anabolic and filter activities and hence protein stores in this wild goat species.

According to our second prediction, sexual differences were observed in the amount of KFs and Ks and in the period in which body stores change from negative to positive values. Given that, after a period of fasting, organ recovery is a greater priority than fatty tissues (Kabbali et al. 1992b), both sexes recovered their KFs levels only once their Ks had peaked. However, this occurred 1 month later in females (July) than in males (June), which might be due to maternal allocation to kids (Barboza and Parker 2008). For ungulates characterised by sexual dimorphism, absolute metabolic costs are higher for larger males and relative energy costs (per kilogramme) differ between sexes according to the season (Parker et al. 2009). Typically, the energetic requirements of female ungulates increase during the first month post-partum, while for males mass-specific seasonal requirements are highest during the breeding period when animals are more active (Toïgo et al. 2007). In the Sierra Nevada, most births occur in May, coinciding with the depletion of KFs in females. However, for males, the breeding period starts in November, which could explain their low KFs in November-December, but not their low KFs found from August to October. Despite the fact that in the Sierra Nevada the body weight of males and females differs at 3 years of age (Granados et al. 1997), the degree of sexual dimorphism varies between seasons, as in other temperate ungulates (Festa-Bianchet et al. 1996). For example, in late spring (May to June), body weights in males (mean body weight $=54.32 \mathrm{~kg}, \mathrm{SE}=11.7$ ) were 1.6 times higher than in females (mean body weight $=33.3 \mathrm{~kg}$, $\mathrm{SE}=12.8$ ); in autumn (September to November) this difference increased by 0.23 points (mean body weight= $60.6 \mathrm{~kg}, \mathrm{SE}=12.6$ vs mean body weight $=33.1 \mathrm{~kg}$, $\mathrm{SE}=11.15$, males and females, respectively). This suggests that, even though the energetic costs of males are higher during most of the year, in the Sierra Nevada male goats may only be able to compensate for their higher energetic requirements at the time of peak of primary productivity (from May to July) and not during the other seasons. Nevertheless, reproductive status is a key factor for understanding seasonal variations in body reserves in dimorphic ungulates, although more research is still required to clarify our results especially between females with different reproductive status.

As per our third prediction, the flexibility of fat reserves is age class dependent in Iberian wild goats. Body condition in the two younger classes was especially affected by environmental variability, as has been described in previous studies of cervids (Hjeljord and Histøl 1999; Garroway and Broders 2005; Torbit et al. 1985a) and bovids in temperate ecosystems (Crampe et al. 2002). In winter, yearlings and young depleted their KFs to a greater extent than adults, thus revealing the widespread vulnerability of young animals in winter. In addition, compared with young and adults, yearling wild goats needed an additional season to restore their fat reserves since the trade-off between growth and maintenance is critical during the first year of life. In fact, the skeletal size of yearlings is half that of adult goats. On the other hand, adults were much more able to increase their KFs during autumn and were able to store four times more KFs than yearlings (estimated as the "average KFs value for adults/average KFs for yearling') and 1.4 times more KFs than young animals. These results could suggest the greater ability of adults to increase their body reserves during the warm season due to their greater foraging efficacy as has been observed in related species (Ruckstuhl et al. 2003). 
Snowfall plays a key role in wild goat body reserves in the Sierra Nevada, and animals had lower KFs and Ks during shallow snow than warm winters, thus mirroring the pattern described for other cervids in temperate ecosystems (Tyler 1986). However, wild goats depleted their KFs most of all in snowy winters, underlying the fact that winter severity increases the energetic requirements of northern ungulates, probably as a result of the increased costs of thermoregulation and reduced food availability. Additionally, goats' Ks in winter-spring were positively correlated with winter severity, suggesting thus that the depletion of fat reserves reduces kidney catabolism. Moreover, wild goats reached their best summer-autumn body condition (Ks and KFs) after the snowiest winters, emphasising the delayed effects of snowfalls on plant productivity during the warm season (Walker et al. 1994) and thus indirectly on the performance of this kind of mountain herbivores.

Both the KFs and Ks of wild goats was clearly densitydependent, as stated in our fourth prediction and in analogous work conducted on other ungulate species (Igota et al. 2004). The dependence on winter body stores observed in this population suggests that goat densities in summer influences goats' ability to satisfy their energetic requirements during the following winter. Nevertheless, for KFs at least-and in agreement with the cumulative effect of winter severity and density observed in several cervid species (Mech et al. 1987; Patterson and Power 2002) density dependence increases above all in the snowiest winters. Neither KFs nor Ks seemed to be affected by the amount of snow that fell during the first year of life, although both these indicators of body condition were affected by winter severity during the last year of life. In the Himalayan tahr, environmental conditions during the first year of life seem to be delayed effects on the subsequent individual KFI, where KFI is defined as the percentage of fat stored around the kidneys (Riney 1955). However, our data illustrates that KFI is more closely correlated to body weight $\left(r=0.34, F_{1,461}=59.25, p<0.05\right)$ than to either KFs $\left(r=0.13, F_{1,461}=9.005, p<0.05\right)$ or $\mathrm{Ks}\left(r=0.004, F_{1,461}=\right.$ 4.1e-20, $p=1)$, suggesting that any cohort effect detected when KFI is the responsible variable may be due to an undesired correlation with body weight.

Herbivores cannot take advantage of sudden temporary increases in food availability for increasing their body reserves and need to feed over long periods of time to restore their body stores (Barboza and Hume 2006). In general, after warm winters, ungulates only have a short period (compared with colder years) in which to access highly nutritious plants, consequently changes in climatic conditions and plant phenology produce a severe effect on phenotypic variation in ungulates, especially in northern species (Lesage et al. 2001; Pettorelli et al. 2007; Post and Stensen 1999). More frequent dry winters are expected to occur in mountain ecosystems as a result of climatic warming (Parmesan 2006), above all in the Mediterranean Basin (Hurrell and van Loo 1997). Thus, changes in lifehistory traits and especially in the pattern of body stores are expected to occur in the wild goats of the Sierra Nevada and, in particular, in young age-classes and males.

Monitoring fat reserves by using mass-size residuals is technically possible due to the fact that the observed relationship between mass-size residuals and direct measurements of body condition (the fat stored around kidneys) fulfils one of the main conditions for the correct use of this method (Green 2001). Although this non-invasive method has been successfully used in several species of reptiles, birds and small mammals (Schulte-Hostedde et al. 2005; Schulte-Hostedde et al. 2001), to our knowledge, it has not yet been validated in ungulates. Nonetheless, in our case, the effect size of the relationship between mass-size residuals and the fat reserves is very low preventing their use for monitoring fat stores of this species. However, in a recent work, Sarasa et al., (2010) and co-workers found an interesting and clear relationship between the mass-size residuals and the allocation to testis in males of this species. These contradictory results may indicate that even if the mass-size residuals is a poor indicator of fat stores, it could be used as a proxy of body condition (a term that includes both 'body stores' and 'body reserves', see the Introduction section). The Iberian wild goat is only just returning to its former range after a significant decrease in numbers in recent centuries (Pérez et al. 2002). Monitoring the relationship between body reserves (especially in culled animals), population densities and climatic parameters should thus be undertaken in order to understand the potential consequences of global warming on the energetic budget of this Caprinae species and its relatives.

Acknowledgments We are grateful to J. Navarro, M. A. López, A. R. Huete, M. C. Pérez and J. García for their help with the field and laboratory work. We would also like to thank David Forsyth, John P. Ball, A. J. M. Hewison, G. Gonzalez, J. F. Gerard and Sandro Lovari for helpful comments on previous drafts of this manuscript. Marco Festa-Bianchet, G. Hilton and A. Schulte-Hostedde participated in stimulating discussions on the best way of estimating wild goat body stores. Special thanks go to Marcus Clauss and Jean Michel-Gaillard for their constructive criticism on the manuscript. E. Serrano is supported by the Juan de la Cierva Postdoctoral Programme of the MICINN (Spain) and M. Sarasa by a MENRT grant (France). Research activities were also partially supported by the Plan Andaluz de Investigación, Junta de Andalucía (RNM-118). Climatologic data were kindly provided by Cetursa, Sierra Nevada, S.A.

\section{References}

Anderson DR, Burnham KP, White GA (2001) Kullback-Leibler information in resolving natural resource conflicts when definitive data exist. Wildl Soc Bull 29:1260-1270 
Andersson MB (1994) Sexual selection. Princeton University Press, Princeton, New York, USA

Barboza PS, Hume ID (2006) Physiology of intermittent feeding: integrating responses of vertebrates to nutritional deficit and excess. Physiol Biochem Zool 79:250-264

Barboza PS, Parker KL (2008) Allocating protein to reproduction in Artic reindeer and caribou. Physiol Biochem Zool 81:835-855

Bishop CJ, Unsworth JW, Garton EO (2005) Mule deer survival among adjacent populations in southwest Idaho. J Wildl Manage 69:311-321

Brown RD, Hellgre EC, Abbott M, Ruthven DC, Bingham RL (1995) Effects of dietary energy and protein restriction on nutritional indices of female white-tailed deer. J Wildl Manage 59:595-609

Buckland ST, Anderson DR, Burnham KP, Laake JL, Borchers DL, Thomas L (2001) Introduction to distance sampling: estimating abundance of biological populations. Oxford University Press, USA

Burnham KP, Anderson DR (2002) Model selection and multimodel inference: a practical information-theoretic approach. SpringerVerlag, New York, USA

Burrin DG, Britton RA, Ferrell CL, Bauer ML (1992) Level of nutrition and synthetic capacity and nucleic acid content in sheep. J Anim Sci 70:1137-1145

Burrin DG, Ferrel CL, Britton RA, Bauer ML (1990) Level of nutrition and visceral organ size and metabolic activity in sheep. Br J Nutr 64:439-448

Chen X (1996) Studying school size effects in line transect sampling using the kernel method. Biometrics 52:1283-1294

Choquenot D (1991) Density-dependent growth, body condition, and demography in feral donkeys: testing the food hypothesis. Ecology 72:805-813

Christians JK (1999) Controlling for body mass effects: is part-whole correlation important? Physiol Biochem Zool 72:250-253

Clutton-Brock TH, Albon SD, Guinness FE (1981) Parental investment in male and female offspring in polygynous mammals. Nature 289:478-489

Consejería de Medio Ambiente (2004) Sierra Nevada: basic data. Grupo Entorno, Granada, Spain

Crampe JP, Gaillard J-M, Loison A (2002) Winter snowfall: a variable factor in recruitment by isard populations (Rupicapra pyrenaica pyrenaica). Can J Zool 80:1306-1312

Dailey TV, Hobbs NT (1989) Travel in Alpine terrain: energy expenditures for locomotion by mountain goats and bighorn sheep. Can J Zool 67:2368-2375

Fandos P (1991) La cabra montés (Capra pyrenaica) en el Parque Natural de las sierras de Cazorla Segura y las Villas. ICONACSIC, Madrid, Spain

Fandos P, Vigal CR, Fernandez-Lopez JM (1987) Weight estimation of Spanish ibex, Capra pyrenaica, and chamois, Rupicapra rupicapra (Mammalia, Bovidae). Mamm biol (formerly Zeitschrift für Säugetierkunde) 54:239-242

Ferguson MAD, Messier F (2000) Mass emigration of arctic tundra caribou from a traditional winter range: population dynamics and physical condition. J Wildl Manage 64:168-178

Ferrel CL, Jenkins TG (1985) Cow type and the nutritional environment: nutritional aspects. J Anim Sci 61:725-741

Festa-Bianchet M, Jorgenson J, King WJ, Smith KG, Wishart WD (1996) The development of sexual dimorphism, seasonal and lifetime mass changes in bighorn sheep. Can J Zool 74:330342

Festa-Bianchet M, Jorgenson JT, Réale D (2000) Early development, adult mass, and reproductive success in bighorn sheep. Behav Ecol 11:633-639

Flydal K, Reimers E (2002) Relationship between calving time and physical condition in three wild reindeer Rangifer tarandus populations in southern Norway. Wildl Biol 8:145-151
Forsyth DM, Duncan RP, Tustin KG, Gaillard J-M (2005) A substantial energetic cost to male reproduction in a sexually dimorphic ungulate. Ecology 86:2154-2163

García-Berthou E (2001) On the misuse of residuals in ecology: testing regression residuals vs. the analysis of covariance. J Anim Ecol 70:708-711

Garroway CJ, Broders HG (2005) The quantitative effects of population density and winter weather on the body condition of white-tailed deer (Odocoileus virginianus) in Nova Scotia, Canada. Can J Zool 83:1246-1256

Goodson AD, Stevens DR, Bailey JA (1991) Effects of snow on foraging ecology and nutrition of bighorn sheep. J Wildl Manage 55:214-222

Granados JE, Fandos P, Márquez FJ, Soriguer RC, Pérez JM (2001) Allometric growth in the Spanish ibex, Capra pyrenaica. Folia Zool 50:234-238

Granados JE, Pérez JM, Soriguer RC, Fandos P, Ruiz-Martinez I (1997) On the biometry of the Spanish ibex Capra pyrenaica, from Sierra Nevada (Southern Spain). Folia Zool 46:9-14

Green AJ (2001) Mass/length residuals: measures of body condition or generators of spurious results? Ecology 82:1473-1483

Hjeljord O, Histøl T (1999) Range-body mass interactions of a northern ungulate: a test of hypothesis. Oecologia 119:326-339

Hurrell JW, van Loo NH (1997) Decadal variations in climate associated with the North Atlantic oscillation. Clim Chang 36:301-326

Igota $\mathrm{H}$, Sakuragi $\mathrm{M}$, Uno $\mathrm{H}$, Kaji $\mathrm{K}$, Kaneko $\mathrm{M}$, Akamatsu R, Maekawa K (2004) Seasonal migration patterns of female sika deer in eastern Hokkaido, Japan. Ecol Res 19:169-178

Jensen PG, Pekins PJ, Holter JB (1999) Compensatory effect of the heat increment of feeding on thermoregulation costs of whitetailed deer fawns in winter. Can J Zool 77:1474-1485

Johnson JB, Omland KS (2004) Model selection in ecology and evolution. Trends Ecol Evol 19:101-108

Jönsson KI (1997) Capital and income breeding as alternative tactics of resource use in reproduction. Oikos 78:57-66

Kabbali A, Johnson WL, Goodrich RD, Allen CE (1992a) Effects of undernutrition and refeeding on weights of body parts and chemical components of growing Moroccan lambs. J Anim Sci 70:2859-2865

Kabbali A, Johnson WL, Johnson DW, Goodrich RD, Allen CE (1992b) Effects of compensatory growth on some body component weights and on carcass and noncarcass composition of growing lambs. J Anim Sci 70:2852-2858

King JR, Murphy ME (1985) Periods of nutritional stress in the annual cycle of endotherms: fact or fiction? Am Zool 25:955-964

Lesage L, Crête M, Ouellet J-P (2001) Evidence for trade-off between growth and body reserves in northern white-tailed deer. Oecologia 126:30-41

Levins R (1968) Evolution in changing environments: some theoretical explorations. Princeton University Press, Princeton, USA

Lindström Å, Piersma T (1993) Mass changes in migrating birds: the evidence for fat and protein storage re-examined. Ibis 135:70-78

Loison A, Langvatn R (1998) Short- and long-term effects of winter and spring weather on growth and survival of red deer in Norway. Oecologia 116:498-500

Martínez T (2000) Diet selection by Spanish ibex in early summer in Sierra Nevada. Acta Theriol 45:335-346

Mech LD, McRoberts RE, Peterson RO, Page RE (1987) Relationship of deer and moose populations to previous winters' snow. J Anim Ecol 56:615-627

Mitchell B, McCowan D, Nicholson IA (1976) Annual cycles of body weight and condition in Scottish red deer, Cervus elaphus. J Zool 180:107-127

Mysterud A, Langvetn R, Stenseth NC (2004) Patterns of reproductive effort in male ungulates. J Zool 264:209-215 
Parker KL, Barboza PS, Gillinngham MP (2009) Nutrition integrates environmental responses of ungulates. Func Ecol 23:57-69

Parmesan C (2006) Ecological and evolutionary responses to recent climate change. Annu Rev Ecol Syst 37:637-669

Patterson B, Power V (2002) Contributions of forage competition, harvest, and climate fluctuation to changes in population growth of northern white-tailed deer. Oecologia 130:62-71

Pélabon C, Gaillard J-M, Loison A, Portier C (1995) Is sex biased maternal care limited by total maternal expenditure in polygnous ungulates. Behav Ecol Sociobiol 37:311-319

Pérez JM, Alpizar-Jara R (2008) Towards the use of distance sampling to monitorize mountain ungulates numbers. In: J Chen, C Guo (eds) Ecosystem Ecology Reserch Trends. Nova Science Publishers. 9-20

Pérez JM, Granados JE, Soriguer RC (1994) Population dynamic of the Spanish ibex Capra pyrenaica in Sierra Nevada Natural Park (southern Spain). Acta Theriol 39:289-294

Pérez JM, Granados JE, Soriguer RC, Fandos P, Márquez FJ, Crampe JP (2002) Distribution, status and conservation problems of the Spanish Ibex, Capra pyrenaica (Mammalia: Artiodactyla). Mammal Rev 32:26-39

Pérez JM, Ruiz-Martinez I, Granados JE, Soriguer RC, Fandos P (1997) The dynamics of sarcoptic mange in the ibex population of Sierra Nevada in Spain: the influence of climatic factors. J Wildl Res 2:86-89

Pérez-Barbería FJ, Mutuberría G, Nores C (1998) Reproductive parameters, kidney fat index, and grazing activity relationships between the sexes in Cantabrian chamois Rupicapra pyrenaica parva. Acta Theriol 43:311-324

Pettorelli N, Pelletier F, von Hardenberg A, Festa-Bianchet M, Côté SD (2007) Early onset of vegetation growth vs rapid green-up: impacts on juvenile mountain ungulates. Ecology 88:381-390

Piersma T, Drent J (2003) Phenotypic flexibility and the evolution of organismal design. Trends Ecol Evol 18:228-233

Post E, Stenseth NC (1999) Climatic variability, plant phenology, and northern ungulates. Ecology 80:1322-1339

R Development Core Team 2. 9. 2 (2009) A language and environment for statistical computing. R Foundation for Statistical Computing, Vienna, Austria. Available at: http://www. R-project.org, Accessed on: 15/12/2009

Riney T (1955) Evaluating condition of free-ranging red deer (Cervus elaphus), with special reference to New Zealand. N Z Jl Sci Technol 36:430-463

Ruckstuhl KE, Festa-Bianchet M, Jorgenson JT (2003) Bite rates in Rocky Mountain bighorn sheep (Ovis canadensis): effects of season, age, sex and reproductive status. Behav Ecol Sociobiol 54:167-173

Sæther BE, Gravem AJ (1988) Annual variation in winter body condition of Norwegian moose calves. J Wildl Manage 52:333-336

Sarasa M, Serrano E, Pérez J, Soriguer R C, Gonzalez G, Joachim J, Granados J E (2010) Effect of season, age and body condition on allocation to testis mass in Iberian ibex. J Zool. doi: 10.1111/ j.1469-7998.2009.00689.x:

Schulte-Hostedde AI, Millar JS, Hickling GJ (2001) Evaluating body condition in small mammals. Can J Zool 79:1021-1029

Schulte-Hostedde AI, Zinner B, Millar JS, Hickling GJ (2005) Restitution of mass-size residuals: validating body condition indices. Ecology 86:155-163
Scmidt-Nielsen B, O'Dell R (1961) Structure and concentrating mechanism in the mammalian kidney. Am J Physiol 200:11191124

Serrano E, Alpizar-Jara R, Morellet N, Hewison AJM (2008a) A half a century of measuring ungulate body condition using indices: is it time for a change? Eu J Wildl Res 54:675-680

Serrano E, González FJ, Granados JE, Moço G, Fandos P, Soriguer RC, Pérez JM (2008b) The use of total serum proteins and tryglycerides for monitoring body condition in the Iberian wild goat (Capra pyrenaica). J Zoo Wild Med 39:646-649

Serrano E, Pérez JM, Christiansen P, Gállego L (2006) Sex-difference in the ossification rate of the appendicular skeleton in Capra pyrenaica Schinz, 1838, and its utility in the sex identification of long bones. Anat Histol Embryol 35:69-75

Stamps JA (1993) Sexual size dimorphism in species with asymptotic growth. Biol J Linn Soc 50:123-145

Stewart KM, Bowyer RT, Dick BL, Johnson BK, Kie JG (2005) Density-dependent effects on physical condition and reproduction in North American elk: an experimental test. Oecologia 143:85-93

Thomas L, Laake JL, Bishop JRB, Marques FFC, Buckland ST, Borchers DL, Anderson DR, Burnham KP, Hedley SL, Pollard JH, Bishop JRB, Marques TA (2005) Distance 5.0. beta 4 . Research Unit for Wildlife Population Assessment; University of St. Andrews. Available at: http://www.ruwpa.st-and.ac.uk/ distance/Accessed on 12/04/2009

Toïgo C, Gaillard J-M, Festa-Bianchet M, Largo E, Michaellet J, Maillard D (2007) Sex- and age-specific survival of the highly dimorphic Alpine ibex: evidence for a conservative life-history tactic. J Anim Ecol 76:679-686

Torbit SC, Carpenter LH, Swift DM, Alldredge AW (1985) Differential loss of fat and protein by mule deer during winter. J Wildl Manage 49:80-85

Tyler NJC (1986) The relationship between fat content of Svalbard reindeer in autumn and their death from starvation in winter. Rangifer 1:311-314

Varios A (1987) La vegetación de España. Universidad de Alcalá de Henares, Alcalá de Henares, Spain

Verme LJ, Ozoga JJ (1980) Effects of diet on growth and lipogenesis in deer fawns. J Wildl Manage 44:315-324

Vincent JP, Hewison AJM, Angibault J-M (1995) The influence of increasing density on body weight, kid production, home range and winter grouping in roe deer (Capreolus capreolus).-Journal of Zoology, London 236:371-382.

Visscher DR, Merrill EH, Fortin D, Frair JL (2006) Estimating woody browse availability for ungulates at increasing snow depths. For Ecol Manage 222:348-354

Walker MD, Webber PJ, Arnold EH, Eberte-May D (1994) Effects of interannual climate variation on aboveground phytomass in Alpine vegetation. Ecology 75:393-408

Wood S (2006) Generalized additive models: an introduction with R. CEC Statistic, Boca Raton, USA

Yokoyama M, Onuma M, Suzuki M, Kaji K (2001) Seasonal fluctuations of body condition in northern sika deer on Hokkaido Island, Japan. Acta Theriol 46:419-428

Zuur AF, Ieno EN, Walker NJ, Saveliev AA, Smith GM (2009) Mixed effects models and extension in ecology with R. Springer, New York, USA 